\title{
mTOR-dependent dysregulation of autophagy contributes to the retinal ganglion cell loss in streptozotocin-induced diabetic retinopathy
}

\author{
Sanjar Batirovich Madrakhimov ${ }^{1,2 \dagger}$, Jin Young Yang ${ }^{1,2 \dagger}$, Jin Ha Kim³ ${ }^{3}$ Jung Woo Han ${ }^{3}$
} and Tae Kwann Park ${ }^{1,2,3,4,5,6^{*}}$ (D)

\begin{abstract}
Background: Neurodegeneration, an early event in the pathogenesis of diabetic retinopathy (DR), precedes clinically detectable microvascular damage. Autophagy dysregulation is considered a potential cause of neuronal cell loss, however underlying mechanisms remain unclear. The mechanistic target of rapamycin (mTOR) integrates diverse environmental signals to coordinate biological processes, including autophagy. Here, we investigated the role of mTOR signaling in neuronal cell death in DR.

Methods: Diabetes was induced by a single intraperitoneal injection of streptozotocin and tissue samples were harvested at 1, 2, 3, 4, and 6 months of diabetes. Early-stage of DR was investigated in 1-month-diabetic mice treated with phlorizin (two daily subcutaneous injections at a dose of $200 \mathrm{mg} / \mathrm{kg}$ of body weight during the last 7 full days of the experiment and the morning of the 8 th day, $3 \mathrm{~h}$ before sacrifice) or rapamycin (daily intraperitoneal injections, at a dose of $3 \mathrm{mg} / \mathrm{kg}$ for the same period as for phlorizin treatment). The effect of autophagy modulation on retinal ganglion cells was investigated in 3-months-diabetic mice treated with phlorizin (two daily subcutaneous injections during the last 10 full days of the experiment and the morning of the 11th day, $3 \mathrm{~h}$ before sacrifice) or MHY1485 (daily i.p. injections, at a dose of $10 \mathrm{mg} / \mathrm{kg}$ for the same period as for phlorizin treatment). Tissue samples obtained from treated/untreated diabetic mice and age-matched controls were used for Western blot and histologic analysis.
\end{abstract}

Results: mTOR-related proteins and glucose transporter 1 (GLUT1) was upregulated at 1 month and downregulated in the following period up to 6 months. Diabetes-induced neurodegeneration was characterized by an increase of apoptotic marker — cleaved caspase 3, a decrease of the total number of cells, and NeuN immunoreactivity in the ganglion cell layer, as well as an increase of autophagic protein. Insulin-independent glycemic control restored the mTOR pathway activity and GLUT1 expression, along with a decrease of autophagic and apoptotic proteins in

\footnotetext{
*Correspondence: tkpark@schmc.ac.kr

† Sanjar Batirovich Madrakhimov and Jin Young Yang contributed

equally to the work presented here and should therefore be regarded as equivalent first authors

${ }^{1}$ Department of Interdisciplinary Program in Biomedical Science,

Soonchunhyang Graduate School, Bucheon Hospital, Bucheon, South

Korea

Full list of author information is available at the end of the article
} permits use, sharing, adaptation, distribution and reproduction in any medium or format, as long as you give appropriate credit to the original author(s) and the source, provide a link to the Creative Commons licence, and indicate if changes were made. The images or other third party material in this article are included in the article's Creative Commons licence, unless indicated otherwise in a credit line to the material. If material is not included in the article's Creative Commons licence and your intended use is not permitted by statutory regulation or exceeds the permitted use, you will need to obtain permission directly from the copyright holder. To view a copy of this licence, visit http://creativecommons.org/licenses/by/4.0/. The Creative Commons Public Domain Dedication waiver (http://creativeco mmons.org/publicdomain/zero/1.0/) applies to the data made available in this article, unless otherwise stated in a credit line to the data. 
3-months-diabetic mice neuroretina. However, blockade of autophagy using MHY1485 resulted in a more protective effect on ganglion cells compared with phlorizin treatment.

Conclusion: Collectively, our study describes the mechanisms of neurodegeneration through the hyperglycemia/ mTOR/autophagy/ apoptosis pathway.

Keywords: Diabetic retinopathy, Neurodegeneration, Autophagy, Apoptosis, The mechanistic target of rapamycin (mTOR)

\section{Background}

Diabetic retinopathy (DR) is a severe ocular complication of diabetes mellitus (DM) leading to vision loss in adults aged 20-79 years [1, 2]. The prevalence of DR ranges from 21.7 to $34.6 \%$ among diabetic individuals [2-5], whose number was estimated at 451 million of adults in 2017 and is projected to increase to 693 million worldwide by 2045 [6]. Despite the introduction of various screening programs for DR detection, it remains the leading cause of blindness for 2.6 million adults among the global population $[7,8]$.

DR is a multifactorial disease with extremely complex mechanisms of development [9]. DR is classified into non-proliferative diabetic retinopathy and proliferative diabetic retinopathy [10, 11]. These "early" and "advanced" stages are characterized by the level of microvascular and ischemic damage of the retina, which determines visible clinical manifestations [11]. However, advances in retinal imaging techniques and electrophysiological studies demonstrated subtle functional deficits and neuronal abnormalities in patients without background retinopathy [12-19]. Experimentally, aside from compromise of vascular cells, alterations of various retinal neuronal cells, macroglia and microglia have been shown in diabetes [20-27]. Thus, the classic view on DR as the microcirculatory pathology evolved into the concept of disease of the retinal neurovascular unit (NVU), where neurodegeneration precedes clinically detectable microvascular damage [11, 28-31].

The concept of retinal NVU describes neurons, glial, and vascular cells as a functional and structural integration, which is essential for maintaining the homeostasis in the inner retina [11, 28-30,32]. Under diabetic conditions, such as hyperglycemia, abnormal blood flow, and others, the NVU appears to be an adaptive mechanism, which fails after prolonged metabolic perturbations [29, 31]. All components of the NVU are affected by diabetes, but which cells are primarily involved in pathologic processes remain unclear [32, 33]. Although vascular, glial, and neuronal cell damage appears to be interdependent, the latter significantly contributes to the development of DR by triggering molecular events resulting in the blood-retinal-barrier dysfunction, microangiopathy, and the proinflammatory milieu [28, 31, 33, 34]. One of the hallmarks of neuronal cell damage is persistent apoptosis, which may be initiated by several pathways, such as glutamate excitotoxicity, loss of neuroprotective factors, oxidative stress, and neuroinflammation [31, $34,35]$. However, growing evidence suggests that defective autophagy also contributes to the diabetes-induced neuronal cell death [36-39]. Autophagy is an adaptive mechanism that may be upregulated against various stress conditions, such as nutrient deprivation, oxidative stress, and others to maintain cellular homeostasis by lysosomal degradation of damaged intracellular elements, and supplying with nutrients [40-42]. However, dysregulated autophagy may have fatal consequences for the cell, indicating a complex network between autophagy and apoptosis [40-42]. At this point, we wondered that if autophagy dysregulation involved in diabetes-induced neurodegeneration, what is the role of the mechanistic target of rapamycin (mTOR) pathway in this context, which is the master regulator of autophagy. This was a starting point of our investigation and we hypothesized how the mTOR pathway may contribute to the neuronal cell death in the DR (Fig. 1). To address the question, we studied the dynamics of events leading to the neuronal cell death in a streptozotocin(STZ)-induced mouse model of diabetes over 6 months of period. The results demonstrated that activity of the mTOR pathway was initially increased at early period of diabetes and this increase was reversed by insulin-independent glycemic control. At advanced stages of diabetes, we observed downregulation of the mTOR activity accompanying with autophagy activation and neuronal cell loss. Furthermore, the management of hyperglycemia could restore the mTOR activity, inhibit autophagy and prevent neuronal cell death. Interestingly, treatment with the mTOR activator, which is MHY1485, demonstrated a more prominent protective effect on neuronal cells even under hyperglycemic conditions. Therefore, downregulation of mTOR activity by various factors associated with prolonged hyperglycemia may be responsible for the autophagy-induced neuronal cell death in the DR. These findings have implications for the development of mTOR-based therapies to manage autophagy-related neuronal cell death in the early stages of DR. 
Short-term hyperglycemia

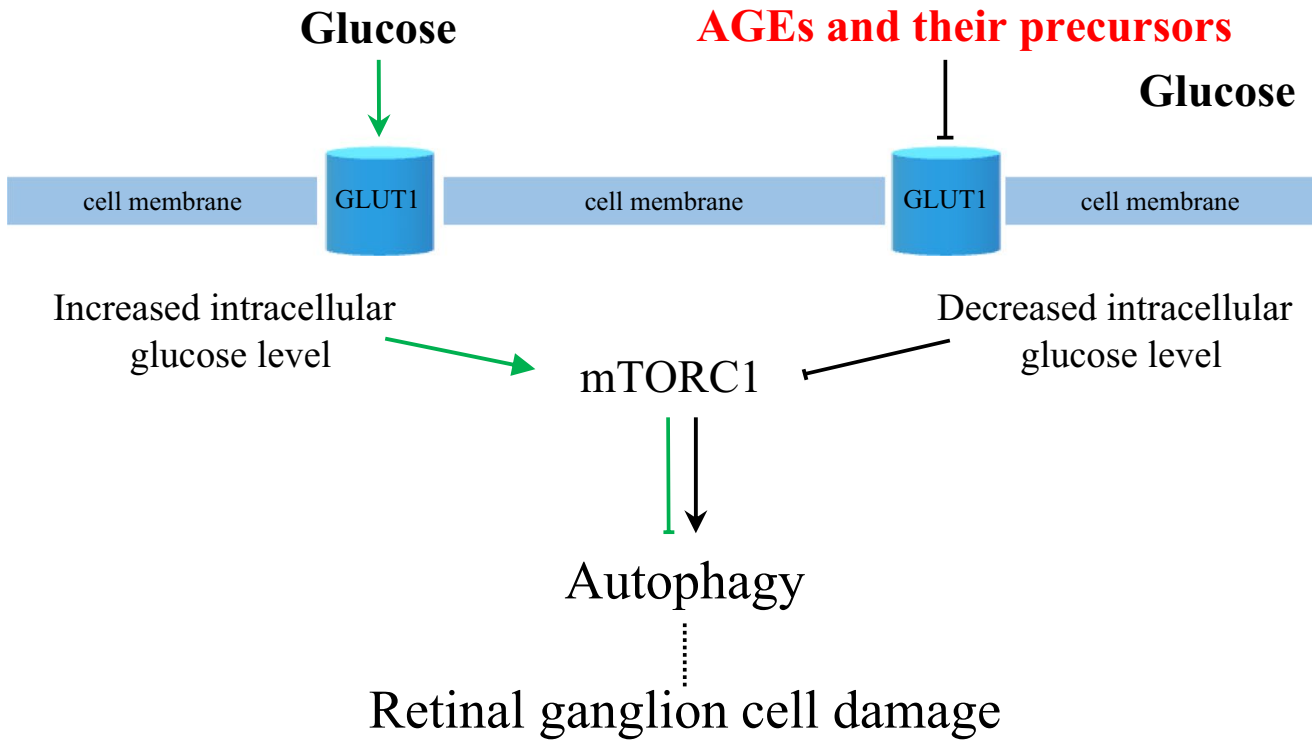

Long-term hyperglycemia

Long-term hyperglycemia

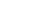


Table 1 Body weight and blood glucose level dynamics

\begin{tabular}{|c|c|c|c|c|c|}
\hline \multirow[t]{2}{*}{ Group } & \multirow[t]{2}{*}{$\mathrm{n}$} & \multirow{2}{*}{$\begin{array}{l}\text { Body weight (gr) } \\
\text { Mean } \pm \text { SD }\end{array}$} & \multirow{2}{*}{ 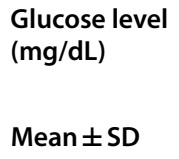 } & \multicolumn{2}{|c|}{$\begin{array}{l}\text { Number } \\
\text { of mice used } \\
\text { for each }\end{array}$} \\
\hline & & & & $\overline{W B}$ & IF \\
\hline \multicolumn{6}{|l|}{$a$} \\
\hline Normal & 10 & $30.5 \pm 1.2$ & $161.9 \pm 14.1$ & 6 & 4 \\
\hline $1 \mathrm{~m} \mathrm{DM}$ & 10 & $21.2 \pm 0.8$ & $448 \pm 51.3$ & 6 & 4 \\
\hline $2 \mathrm{~m} \mathrm{DM}$ & 10 & $24.8 \pm 1.2$ & $458.7 \pm 67$ & 6 & 4 \\
\hline $3 \mathrm{~m} \mathrm{DM}$ & 10 & $25.7 \pm 1.7$ & $467.8 \pm 72.3$ & 6 & 4 \\
\hline $4 \mathrm{~m} \mathrm{DM}$ & 9 & $28.5 \pm 2$ & $500.5 \pm 71.1$ & 6 & 3 \\
\hline $6 \mathrm{~m} \mathrm{DM}$ & 8 & $29 \pm 1.1$ & $481.5 \pm 65.9$ & 5 & 3 \\
\hline \multicolumn{6}{|l|}{$b$} \\
\hline Normal & 10 & $22.25 \pm 0.8$ & $165.5 \pm 20.9$ & 6 & 4 \\
\hline $1 \mathrm{~m} \mathrm{DM}$ & 10 & $21.05 \pm 0.7$ & $488.6 \pm 63.8$ & 6 & 4 \\
\hline 1 m DM/PHL & 10 & $21.4 \pm 1.7$ & $231.3 \pm 43.9$ & 6 & 4 \\
\hline 1 m DM/Rapa & 9 & $20.85 \pm 2.4$ & $461.2 \pm 53.4$ & 6 & 3 \\
\hline \multicolumn{6}{|l|}{ c } \\
\hline Normal & 10 & $27.55 \pm 0.9$ & $163 \pm 14.7$ & 6 & 4 \\
\hline $3 \mathrm{~m} \mathrm{DM}$ & 9 & $25.6 \pm 1.5$ & $466.7 \pm 71.8$ & 6 & 3 \\
\hline 3 m DM/PHL & 9 & $25.9 \pm 1.6$ & $198 \pm 38.9$ & 6 & 3 \\
\hline $3 \mathrm{~m} \mathrm{DM} / \mathrm{MHY}$ & 8 & $24.8 \pm 1.2$ & $470.7 \pm 73.1$ & 5 & 3 \\
\hline
\end{tabular}

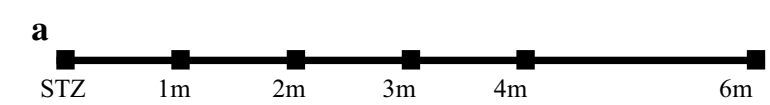

injection

b
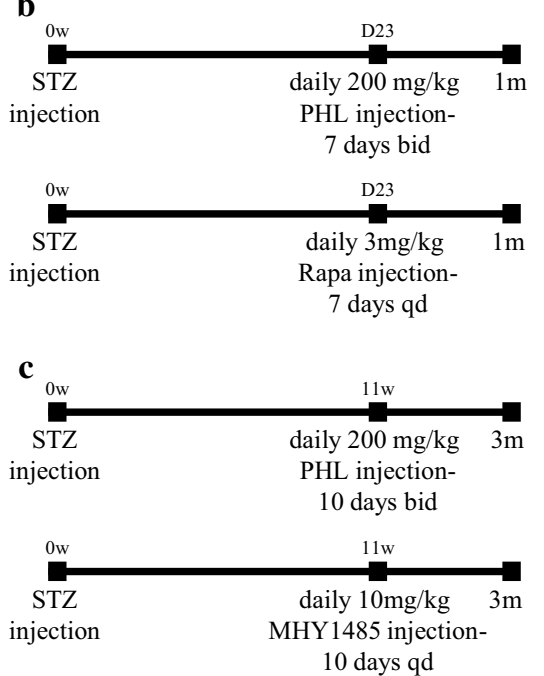

Fig. 2 Study design and general parameters of mice; bid — twice a day, qd-once a day. Table 1 Body weight and blood glucose level dynamics

the $1 \mathrm{~m} \mathrm{DM}$ /Rapa group, received daily i.p. injections of rapamycin (Sigma-Aldrich, St. Louis, MO) diluted in
$4 \%$ ethanol and 5\% Tween-20 in distilled water at a dose of $3 \mathrm{mg} / \mathrm{kg}$ for the same period as for the $1 \mathrm{~m} \mathrm{DM} / \mathrm{PHL}$ group [46]. Rapamycin, a macrolide, inhibits mTORC1 after forming a gain-of-function complex with FKBP12 protein [47].

The effects of long-term hyperglycemia on the retina of diabetic mice were evaluated on 40 mice, divided into 4 groups: (1) Normal control, (2) $3 \mathrm{~m} \mathrm{DM}$, (3) $3 \mathrm{~m}$ $\mathrm{DM} / \mathrm{PHL}$, and (4) $3 \mathrm{~m} \mathrm{DM} / \mathrm{MHY}$ (Fig. 2c). Mice in the $3 \mathrm{~m} \mathrm{DM} / \mathrm{PHL}$ group received two daily subcutaneous injections of PHL during the last 10 full days of the experiment and the morning of the 11th day, $3 \mathrm{~h}$ before sacrifice. Mice in the $3 \mathrm{mDM} / \mathrm{MHY}$ group received daily i.p. injections of MHY1485 (MedChem Express, Monmouth Junction, NJ) at a dose of $10 \mathrm{mg} / \mathrm{kg}$ for the same period as for the $3 \mathrm{~m}$ DM/PHL group. MHY1485, an mTOR activator, inhibits the fusion between autophagosomes and lysosomes, thus downregulates autophagy [48, 49]. Eight diabetic mice died in the course of this study.

\section{Tissue collection and preparation}

After completing the experiment, mice were used for WB and histologic analysis. For histologic analysis, mice were deeply anesthetized by intraperitoneal injection using the mixture of $40 \mathrm{mg} / \mathrm{kg}$ zolazepam/tiletamine (Zoletil 50, Virbac, Carros Cedex, France) and $5 \mathrm{mg} / \mathrm{kg}$ xylazine (Rompun, Bayer Healthcare, Leverkusen, Germany) and perfused intracardially with $0.1 \mathrm{M}$ phosphate buffer (PB) containing $1000 \mathrm{U} / \mathrm{ml}$ of heparin, followed by an infusion of $4 \%$ paraformaldehyde (PFA) in $0.1 \mathrm{M} \mathrm{PB}$. The eyecup was made by removing the anterior segment from the enucleated mouse eye and fixed with $4 \%$ paraformaldehyde (Biosesang, Seongnam, South Korea) for $1 \mathrm{~h}$, dehydrated in $30 \%$ sucrose overnight, and embedded in frozen section compound (Leica Biosystems Richmond, IL). The sample collection for the WB experiment was that the neuroretina was separated from the enucleated mouse eyes, pooled together and stored at $-80{ }^{\circ} \mathrm{C}$ until the experiment.

\section{Western blot}

Neuroretinal tissue was disrupted in RIPA II lysis buffer (Gendepot, Barker, Tx) containing Xpert phosphatase inhibitor cocktail (Gendepot, Barker, Tx) and Xpert protease inhibitor cocktail (Gendepot, Barker, Tx) for $1 \mathrm{~h}$ on the ice. Insoluble material was removed by centrifugation $\left(13,000 \mathrm{rpm}, 15 \mathrm{~min}, 4{ }^{\circ} \mathrm{C}\right)$, and the only supernatant was obtained. Protein lysate was quantified using Pierce BCA Protein Assay kit (Thermo scientific, Middlesex, MA) according to the manufacturer's instruction.

The lysates were denatured in $4 \times$ Laemmli sample buffer (Gendepot, Barker, Tx), boiled for $10 \mathrm{~min}$ at $95{ }^{\circ} \mathrm{C}$. Aliquots of each sample with an equal amount 
of protein were separated using SDS-acrylamide gel in the range from 6 to $10 \%$, depending on the molecular weight of the target antibody and transferred onto polyvinylidene fluoride membrane (ATTO, Amherst, NY). The membranes were incubated with $5 \%$ skim milk in Phosphate-Buffered Saline (PBS) containing 0.1\% Tween-20 for detection of total proteins and 5\% BSA in PBS containing $0.1 \%$ Tween-20 for phosphorylated proteins for $1 \mathrm{~h}$ at room temperature and incubated with anti-mTOR, anti-phospho-S6 ribosomal (pS6) protein (S240/244) from Cell signaling technology (Danvers, MA), anti-phospho-mTOR (S2448), anti-GLUT1 from Abcam (Cambridge, UK), anti- $\beta$-actin from Santa Cruz Biotechnology (Dallas, TX) antibodies overnight at $4{ }^{\circ} \mathrm{C}$; details on antibodies are given in Additional file 1 : Table S1. After washing, the membranes were incubated with horseradish peroxidase (HRP)-conjugated goat anti-rabbit IgG and goat anti-mouse IgG (Genedepot, Barker, Tx) at room temperature for $2 \mathrm{~h}$. The immunoreactive signal was developed using Western blotting detection kit (EzWestLumi plus, ATTO Corporation, Tokyo, Japan) and read with Azure BiosystemsTM c280 (Azure Biosystems, Dublin, CA, USA). Bands on blots were quantified using the Image software (National Institutes of Health, Bethesda, MD).

\section{Immunofluorescence}

Fresh eyecup cryosections $(10 \mu \mathrm{m}$ in thickness) were made with a Cryotome (Thermo Fisher Scientific Shandon Cryotome, Middlesex, MA). The slides were washed with $1 \mathrm{xPBS}$ containing $0.1 \%$ Triton X-100 (Sigma-Aldrich, St. Louis, MO) and blocked with 5\% donkey serum in PBST for $1 \mathrm{~h}$. The blocked slides were then incubated with anti-phospho-mTOR (S2448), anti-GLUT1 from Abcam (Cambridge, UK), antiphospho-S6 ribosomal protein (S240/244) and antiGlial fibrillary acidic protein (GFAP) (CST) from Cell signaling technology (Danvers, MA), anti-Glutamine synthetase (GS) from Millipore (Billerica, MA), anti brain-specific homeobox/POU domain protein 3A (Brn3a) and anti-neuronal nuclear protein (NeuN) from Millipore (Billerica, MA), anti Calbindin (Calb) from Sigma-Aldrich (St. Louis, MO), anti-Cleaved caspase-3 from Cell signaling technology (Danvers, MA), anti-Beclin1 from Novus Biologicals (Littleton, CO) antibodies for $2 \mathrm{~h}$ and detected with secondary antibodies (Alexa Fluor 488 or 568 or 647, dilution 1:1000; Invitrogen Corp., Carlsbad, CA); details on antibodies are given in Additional file 1: Table S1. Nuclear counterstaining was performed with Hoechst 33,342 (Invitrogen Corp, Carlsbad, CA). After washing, the sections were mounted with fluorescence mounting medium (Dako, Santa Clara, CA).

\section{Image analysis and cell counting}

All slides were imaged using a Leica SP8 (Leica Microsystems, Wetzlar, Germany) confocal microscope. Cleaved caspase- $3, \mathrm{NeuN}$ and Hoechst positive cells $(\mathrm{n}=6$ per group) were manually calculated using Image J software (National Institutes of Health, Bethesda, MD).

\section{STRING analysis}

The potential interactions among selected proteins were analyzed using free online database of currently known proteins-STRING (Search Tool for the Retrieval of Interacting Genes, v11.0). IDs of selected proteins were used as an input in the database (http://string-db.org/) to find functional associations in homo sapiens and mus musculus with a minimum interaction score of 0.400 (medium confidence). Active interaction sources included text mining, experiments, databases, gene fusion, co-occurrence, co-expression, and neighborhood.

\section{Statistical analysis}

Data are expressed as means \pm standard deviation. Differences among groups were analyzed using the MannWhitney U test. Differences were considered statistically significant when $p \leq 0.05$.

\section{Results \\ Hyperglycemia-induced molecular events and consequences in STZ mouse retina}

We observed the effect of hyperglycemia on the expression of mTOR related proteins and GLUT1 for 6 months after induction of diabetes. After 1 month of STZ injection, pmTOR (S2448) and its downstream effector-pS6 (S240/244) levels were upregulated followed by substantial decrease at 2, 3 and 4 months. Six months samples demonstrated the lowest level of pmTOR (S2448) and pS6 expression (Fig. 3a, b). GLUT1 also showed higher levels at one month after diabetes induction, and then gradually decreased by 6 months of observation (Fig. 3a, b).

To evaluate neuronal cell death in the diabetic retina, we immunostained the cryosections of the retina of STZ mice at 1, 3, 6 months for Cleaved caspase- 3 and NeuN, normal mouse retina served as control (Fig. 3c). Cleaved caspase-3 signals were detected in the ganglion cell layer (GCL) of the diabetic retina, which was weak at 1 month and strong at 3 and 6 months (Fig. 3c), positive signal was not observed in normal retina. Counting of Cleaved caspase-3-positive cells demonstrated a gradual increase of apoptotic cell number and a peak after 6 months 


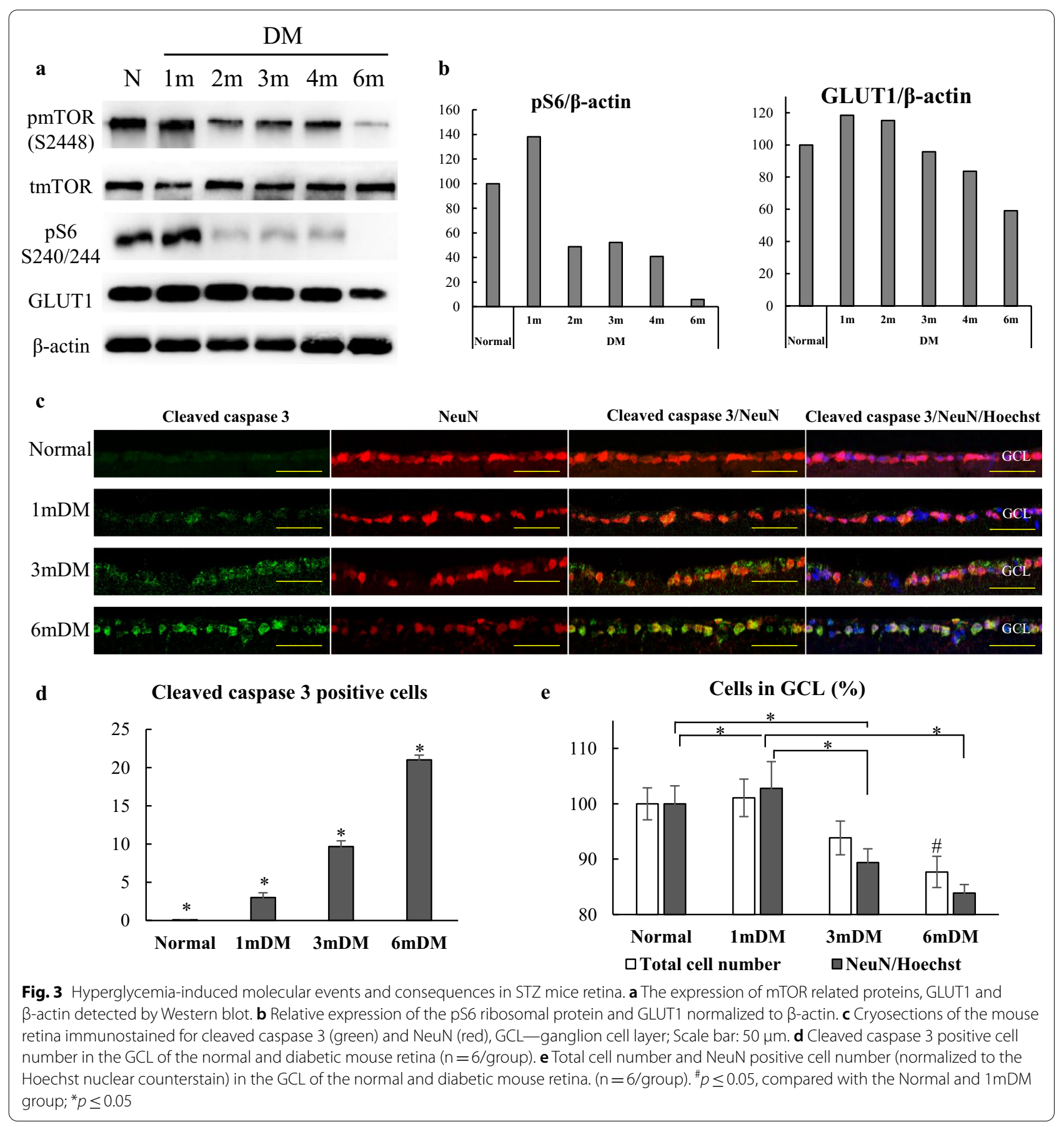

of diabetes induction $(p<0.05$, Fig. 3d). In addition, NeuN immunoreactivity of ganglion cells progressively decreased at 3 and 6 months, which was also confirmed by counting of NeuN-positive cells $(p<0.05)$ (Fig. 3c, e). The total number of cells in GCL was also decreased after $3(p>0.05)$ and 6 months of diabetes $(p<0.05)$ (Fig. 3e).
pmTOR S2448, pS6 and GLUT1 expressing cells in the normal mouse retina

Next, we performed immunofluorescence assay to identify pmTOR S2448, pS6 and GLUT1 expressing cells in the neuroretina of normal mouse. pmTOR S2448 is expressed in the GCL, in both plexiform layers and the cell bodies in the inner nuclear layer (INL), as was found to be the similar for GLUT1, which was also expressed in 
(See figure on next page.)

Fig. 4 pmTOR S2448, pS6 and GLUT1 expressing cells in the normal mouse retina. Cryosections of normal mouse immuno-co-stained with pmTOR S2448 (green) and GLUT1 (red) (a), or NeuN (red) (b), or Calbindin (red) (c), or Glutamine synthetase (GS—red) (d), GS (green) and GLUT1 (red) (e), pS6 (green) and NeuN (red) (f), or Calbindin (red) (g). Nuclei were counter-stained with Hoechst 33,342 (blue). GCL, ganglion cell layer; INL, inner nuclear layer; ONL, outer nuclear layer; Scale bar: $50 \mu \mathrm{m}$

the cell bodies of the outer nuclear layer (ONL) (Fig. 4a). Co-immunostaining of pmTOR S2448 and NeuN confirmed the expression of activated mTORC1 in ganglion cells (Fig. 4b). Phosphorylated mTOR at S2448 was also expressed in Calbindin positive cells (Fig. 4c). Moreover, pmTOR S2448 is expressed in the endfeet and cell bodies of Müller cells immunostained for Glutamine synthetase (GS, Fig. 4d), which was also co-localized with GLUT1 (Fig. 4e).

The downstream effector of mTORC1 complex, pS6, was found to be expressed highly in the GCL and the outermost part of the INL, weakly in the cell bodies in the inner half of the INL. While the source of the pS6 signal in the GCL was NeuN-positive ganglion cells (Fig. 4f), signals from the outermost part of the INL originated from the cell bodies and processes of horizontal cells immunostained for Calbindin (Fig. 4g). Weak pS6 signal colocalized with NeuN positive cells in the inner nuclear layer, which are likely to be amacrine cells or ectopic ganglion cells (Fig. 4f).

\section{Dynamics of hyperglycemia-induced pS6 and GLUT1 expression in STZ mouse retina}

After 1 month of hyperglycemia, we observed upregulation of pS6 expression in the inner retina. After 3 months of hyperglycemia, pS6 expression was downregulated, amacrine cells and processes of horizontal cells lacked pS6, while cell bodies of ganglion cells and horizontal cells retained pS6 expression. A few pS6-positive ganglion cells and horizontal cells were observed after 6 months of diabetes (Fig. 5). GLUT1 expression was also increased at 1 month of diabetes and was gradually decreased evenly in the neuroretina at 3 and 6 months of diabetes (Fig. 5).

\section{Hyperglycemia-induced activation of glia and autophagy dysregulation in STZ-mouse retina}

Glia reactivity was detected by immunostaining of cryosections of normal and $3 \mathrm{~m} \mathrm{STZ}$ mouse retina with antibody against glial fibrillary acidic protein (GFAP). In normal mouse retina, GFAP expression was limited to the astrocytes and Müller cell endfeet in the nerve fiber layer (NFL) and GCL (Fig. 6c), whereas in the $3 \mathrm{~m} \mathrm{DM}$ mouse retina, GFAP expression was elevated and extended to the glia in the NFL, GCL and IPL (Fig. 6d). Moreover, in the $3 \mathrm{~m}$ DM mouse retina, pmTOR S2448 expression was evenly downregulated comparing to those of the normal mouse retina (Fig. 6c, d).

To evaluate autophagy flux, we immunostained cryosections of normal and $3 \mathrm{~m} \mathrm{STZ-mouse} \mathrm{retina} \mathrm{for} \mathrm{Bec-}$ lin1. In the normal mouse retina, Beclin1 expression which was detected in the GCL, INL and OPL in the normal mouse retina. Beclin1 immunoreactivity in $3 \mathrm{~m} \mathrm{STZ}$ mouse retina was clearly upregulated and extended to the IPL, ONL and photoreceptor cell layer (Fig. 6a, b).

\section{The effects of short-term hyperglycemia on STZ-mouse retina are reversible by glycemic control}

pmTOR S2448 expression was upregulated at 1 month of diabetes and phlorizin (PHL) treatment demonstrated similar levels as those of normal mouse neuroretina demonstrated by Western Blot and immunofluorescence assay. Hyperglycemia-induced upregulation of pS6, as well as GLUT1 levels, were also decreased by glycemic control with PHL treatment. As expected from mTOR inhibition, rapamycin treatment resulted in decreased expression of pmTOR S2448 and pS6 levels, but we also observed downregulation of GLUT1 (Fig. 7a, b).

Glial response was monitored by immunofluorescence assay. In the normal mouse retina, GFAP expression was confined to astrocytes in the NFL and GCL, whereas in the $1 \mathrm{~m}$ DM retina, astrocytes located in the inner plexiform layer (IPL) were also stained along with rare Müller glia resembling GFAP positive cells. PHL and rapamycin treatment returned the levels of GFAP expression back to the normal state (Fig. 7c).

\section{Autophagy dysregulation contributes to neuronal damage after long-term hyperglycemia}

pmTOR S2448 and pS6 expression was decreased at 3 month of diabetes and PHL treatment recovered mTOR activity in the neuroretina as demonstrated by Western Blot and immunofluorescence assay (Fig. 8a, g). GLUT1 expression in the neuroretina of $3 \mathrm{~m} \mathrm{STZ-mouse} \mathrm{was} \mathrm{also}$ increased following PHL treatment (Fig. 8a). MHY1485 treatment successfully activated mTOR in the neuroretina of $3 \mathrm{~m}$ STZ-mouse, since pmTOR S2448 level detected by WB and immunofluorescence assay, was high.

Beclin1 immunoreactivity in the retina from $3 \mathrm{~m} \mathrm{DM} /$ PHL group resembled the similar expression pattern as those of normal control group: immunofluorescence 


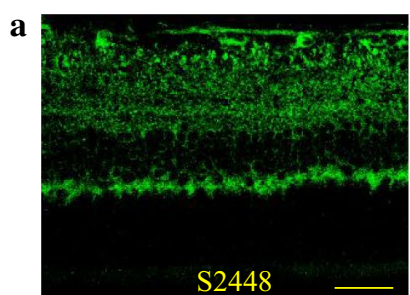

b

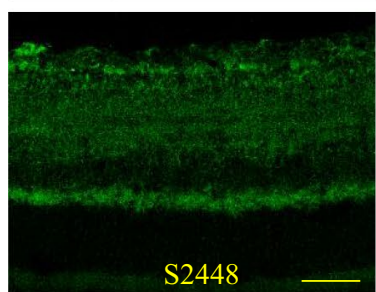

c

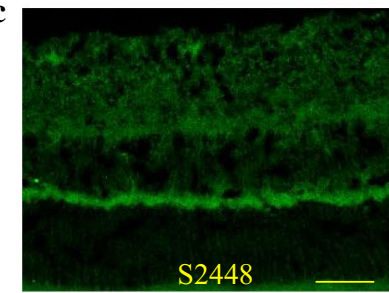

d

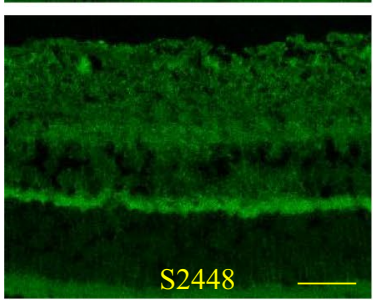

e

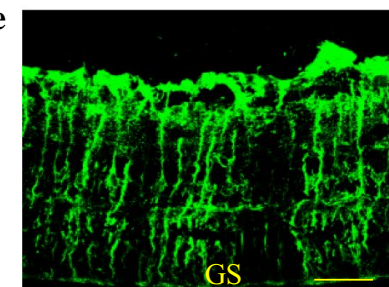

f

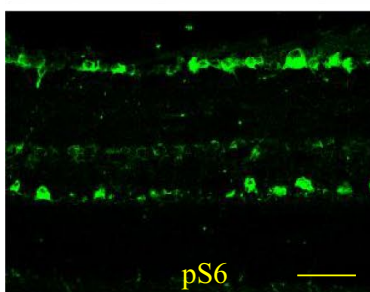

g

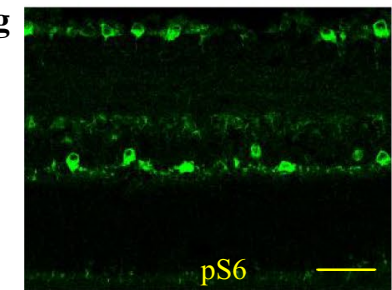

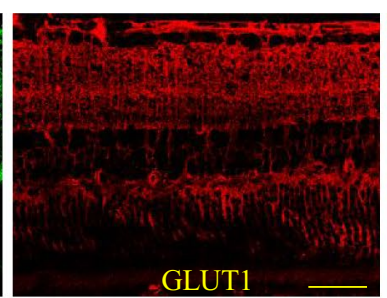
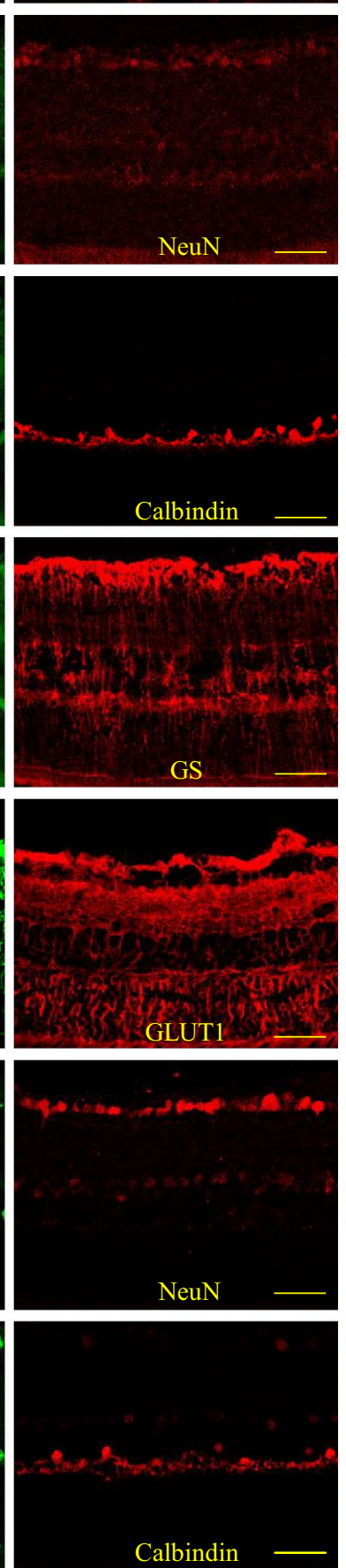
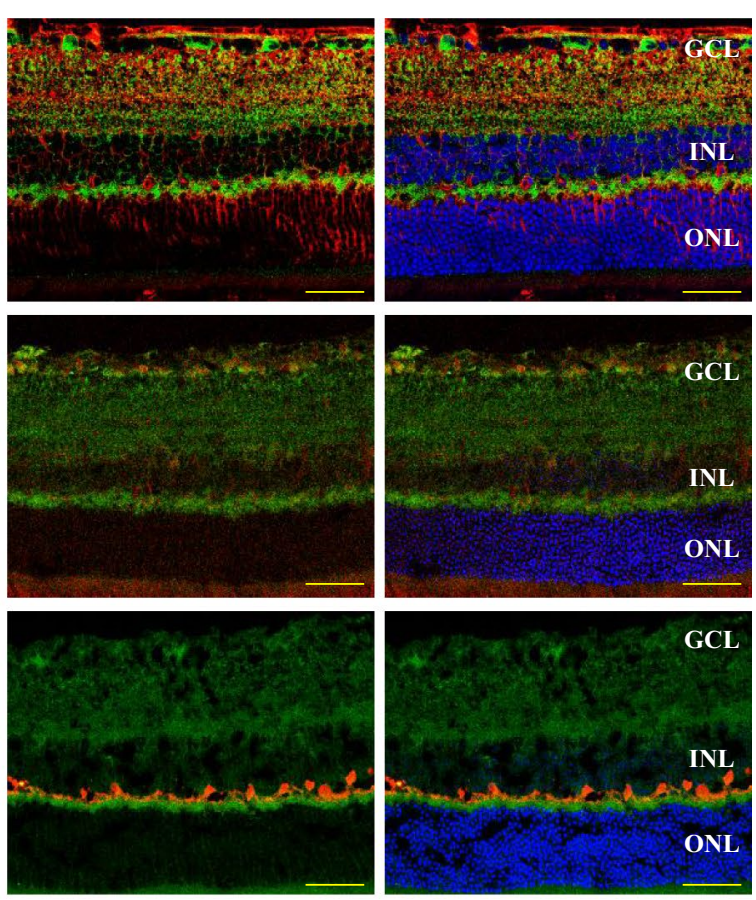

GCL

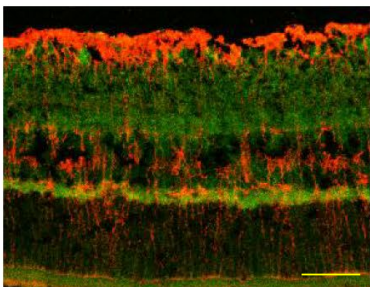

(a)

INL

ONL

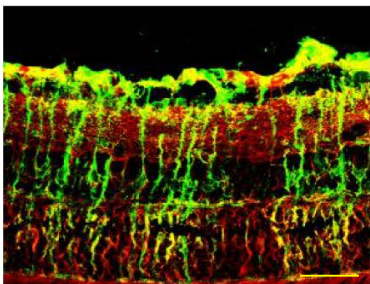

ONL
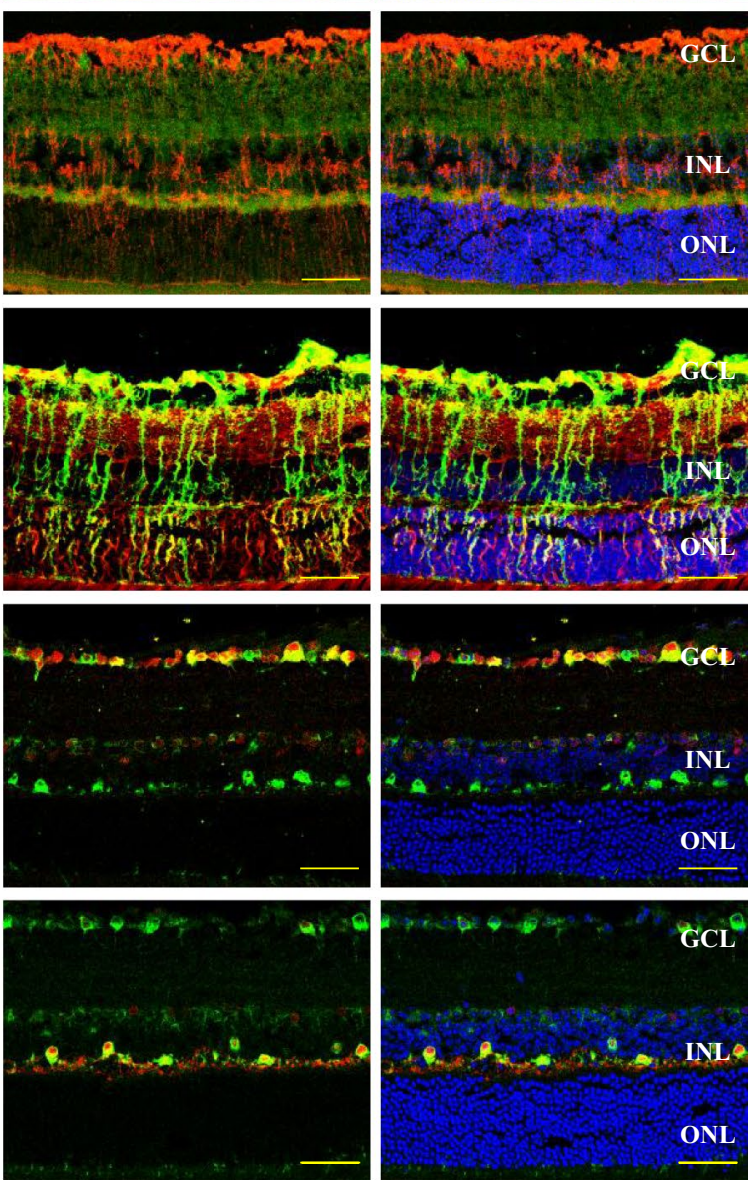


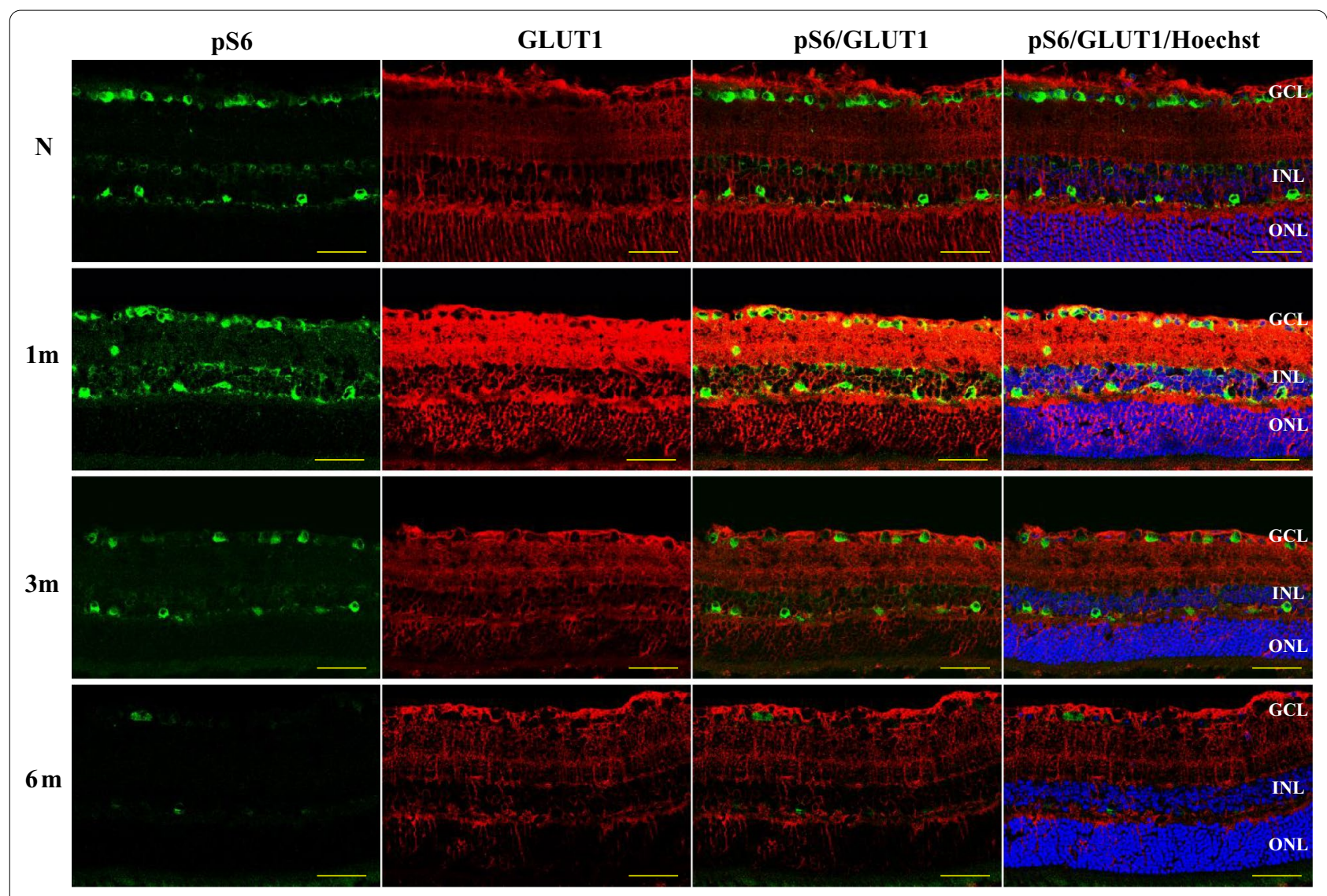

Fig. 5 pS6 and GLUT1 expression dynamics over 6 months of observation of STZ-induced DM mice
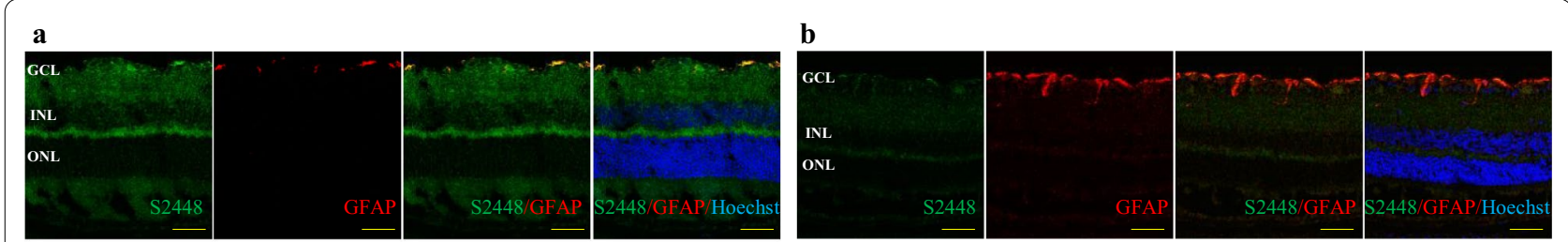

c

d
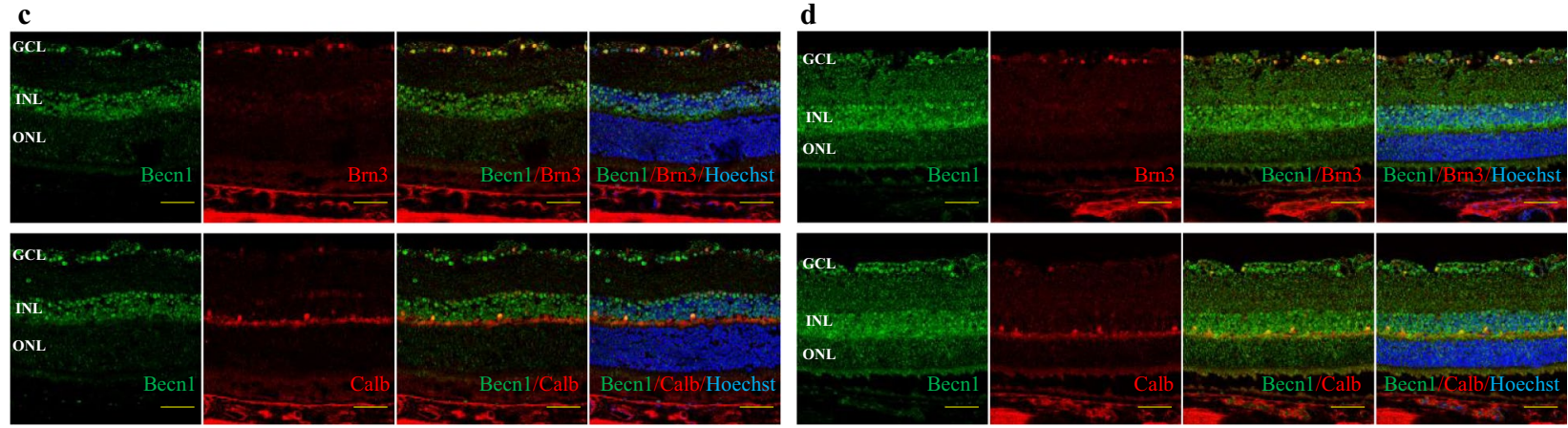

Fig. 6 Autophagy and glia activation in the retina of STZ-induced DM. Immuno-co-staining for pmTOR S2448 (green) and GFAP (red) of normal (a) and $3 \mathrm{~m}$ DM mouse retina (b). Immuno-co-staining for Beclin1 (green) and Brn3 or Calbindin (red) of normal (c) and $3 \mathrm{~m}$ DM mouse retina (d). GCL, ganglion cell layer; INL, inner nuclear layer; ONL, outer nuclear layer; Scale bar: 50 m 


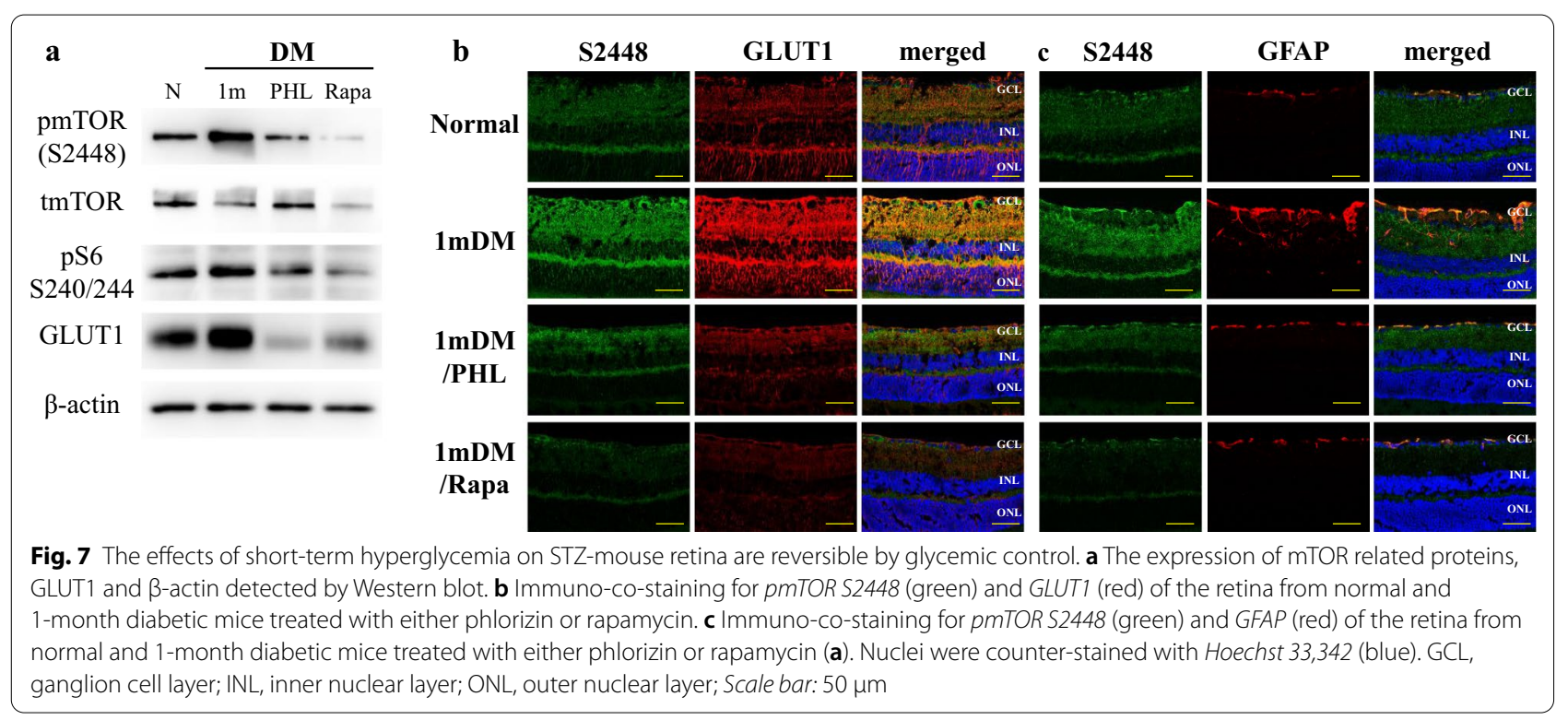

signal was detected in the GCL, INL, and OPL. However, MHY1485 treatment resulted in stronger inhibition of autophagy, since Beclin1 signal was observed only in the GCL (Fig. 8b). Calbindin staining did not reveal any difference in OPL of the retina from all groups; meanwhile, the GCL differed between all experimental groups (Fig. 8b, c).

To assess, how autophagy affects the neuronal cells in the GCL, we immunostained the retinal tissues from $3 \mathrm{mDM}, 3 \mathrm{mDM} / \mathrm{PHL}$ and $3 \mathrm{mDM} / \mathrm{MHY}$ groups for Cleaved caspase 3 and NeuN, retinal tissues from normal mouse served as control. We observed a clear increase in Cleaved caspase 3 labeling in the GCL of $3 \mathrm{~m} \mathrm{STZ}$ mouse, indicating high apoptotic activity after longterm hyperglycemia (Fig. 8d). PHL treatment resulted in moderate decrease of immunoreactivity and number of Cleaved caspase 3 positive cells (Fig. 8d, e). However, autophagy blocking with mTOR activator resulted in significant decrease of immunoreactivity and number of Cleaved caspase 3 positive cells comparing to those of $3 \mathrm{~m} \mathrm{DM}$ and $3 \mathrm{~m} \mathrm{DM} / \mathrm{PHL}$ groups (Fig. 8d, e). Quantification of neuronal cells in the GCL of tissues from treatment groups also confirmed the neuronal cells rescue from apoptotic activity induced by long-term hyperglycemia (Fig. 8f). The total number of cells in GCL was decreased in the retinal tissues from 3mDM group comparing to those of from the normal group and 3mDM/ PHL demonstrated a similar amount of Hoechst positive cells $(p>0.05)$. However, NeuN positive cell number was higher in tissues from $3 \mathrm{mDM} / \mathrm{PHL}$ group comparing to $3 \mathrm{mDM}$ group $(p>0.05)$. In the tissues of the $3 \mathrm{mDM} /$ MHY group, total number of cells and NeuN positive cell was the highest among STZ-injected groups $(p<0.05)$ (Fig. 8f).

To confirm the neuronal rescue following autophagy modulation, we studied the glial response by GFAP labeling (Fig. 8g). GFAP positive astrocytes and Müller glia resembling cells were detected in the NFL, GCL, and IPL of $3 \mathrm{~m}$ STZ-mouse. MHY1485 treated mouse retina demonstrated GFAP signals only in the NFL and GCL as demonstrated normal mouse retina. Similar results were found in those of PHL-treated mice (Fig. 8g).

\section{Discussion}

The major contributor to the development of DR is the high levels of glucose in the blood $[1,50]$. Glucose-the primary energy source of the cell-is a polarized large molecule, which cannot traverse the cell membrane by diffusion. In the retina, the proteins of facilitated diffusion glucose transporter family are proposed to be responsible for glucose transportation [51]. Among others, glucose transporter 1 (GLUT1) is the most studied and considered as the major transporter in the neural retina and blood-retinal barrier (BRB) [51-56]. As being insulin-independent glucose transporter, the GLUT1 expression and transport activity can be stimulated by the levels of glucose in the blood [57, 58]. Under diabetic conditions, hyperglycemia results in an increase of intracellular glucose concentration in the neural retina potentially through hyperglycemiainduced GLUT1 upregulation as an adaptive response [59-61]. However, long-term hyperglycemia may lead to the downregulation of GLUT1 in the retina [62-64]. Differential expression of GLUT1 depending on clinical 


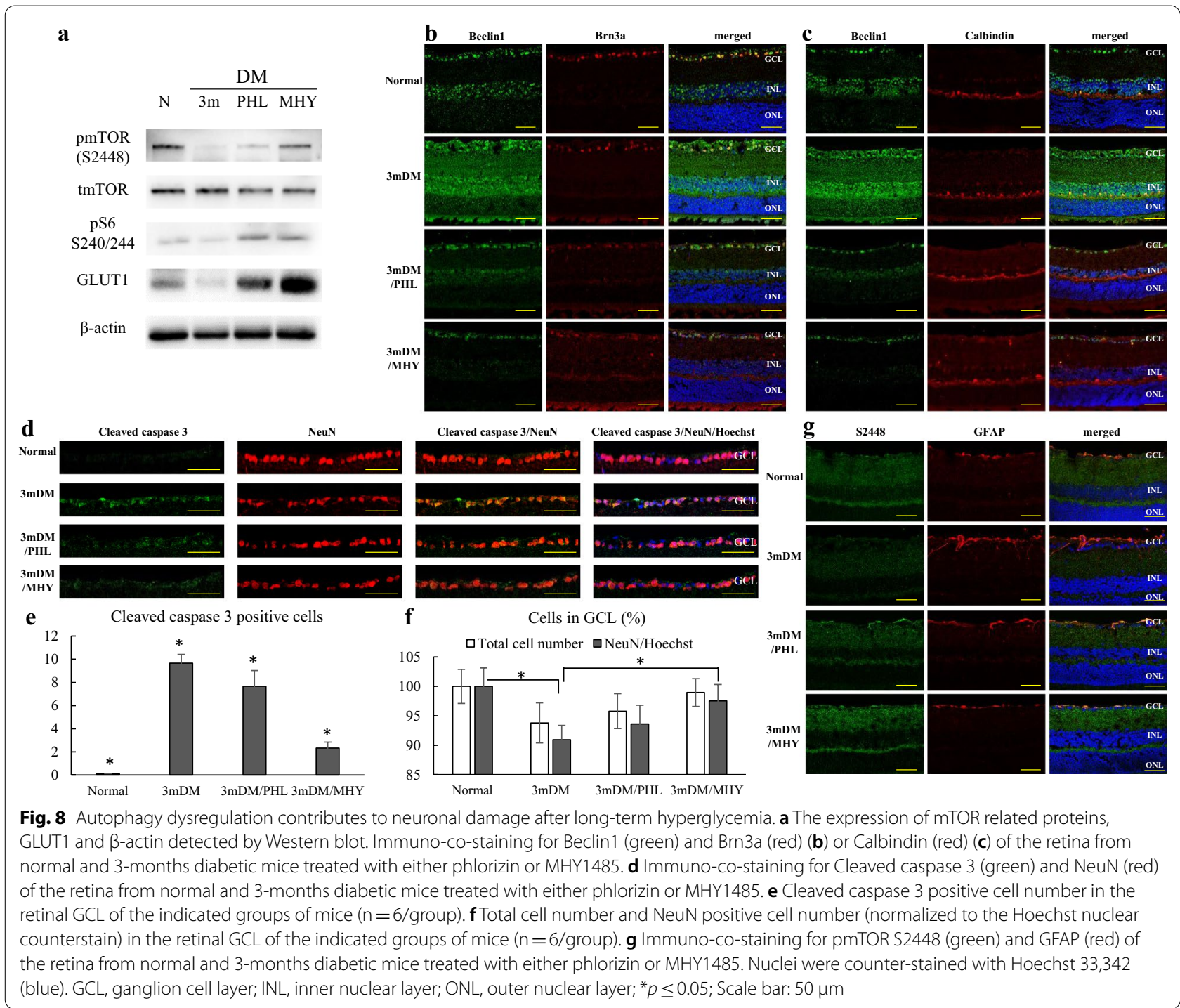

stages of DR was also observed in postmortem human retina $[52,65,66]$. In the inner $B R B$, focal upregulation of GLUT1 expression was observed in long-standing DM patients with minimal or no clinical retinopathy [65]. However, GLUT1 expression was significantly decreased in human eyes with clinically evident DR [66]. Another study reported that GLUT1 immunoreactivity was not even observed in the neovascular tissue of patients with proliferative DR, which is an advanced stage [52]. Several mechanisms of GLUT1 downregulation are implicated upon long-term hyperglycemia including oxidative stress signaling and accumulation of advanced glycation end-products (AGEs) and their precursors, such as methylglyoxal, which, inter alia, may inhibit expression of the glucose transporter genes [6770]. Also, growing data suggests another detrimental effect of long-term hyperglycemia on the retina which is manifested in the generation of autophagy processes through nutrient stress, oxidative stress, endoplasmic reticulum stress, hypoxia, inflammation, and others $[39,41,71]$. At this point, we hypothesized that the mTOR signaling pathway may be the link between the factors related to hyperglycemia and autophagy, consequently leading to the neuronal cell loss in DR (Fig. 1).

mTOR is atypical serine/threonine protein kinase from the phosphoinositide 3-kinase (PI3K)-related kinase family, which maintains the balance between anabolic and catabolic processes in response to a variety of physiological and pathological conditions [72]. mTOR pathway regulates myriad biological processes such as protein synthesis, proliferation, autophagy, metabolism, cell survival, and others through distinct protein complexes including mTOR complex 1 (mTORC1), mTOR complex 2 (mTORC2) and mTOR complex 3 (mTORC3) [72, 73]. 
The most intensively studied of all mTOR complexes is undoubtedly mTORC1. mTORC 1 senses the main intracellular and extracellular signals, which are nutrient levels, growth factors, oxygen, amino acids, and stress, to regulate variety of essential metabolic processes, such as protein synthesis and autophagy [72].

High levels of nutrients, such as intracellular hyperglycemia directly or indirectly activates mTORC1 resulting in increased anabolism [72, 74]. In vitro experiments demonstrated that increased extracellular glucose stimulates GLUT1 expression and mTORC1 pathway, moreover, adenoviral overexpression of GLUT1 had similar effect on the latter [75]. Another study demonstrated that knockdown or inhibition of GLUT1 decreases retinal glucose, superoxide radicals and vascular endothelial growth factor in the early period of diabetes [76]. Activation of mTORC1 pathway in the early period of diabetes ( 28 days) has previously been reported in the retina of STZ-induced rat model [77]. In our study, 6 months monitoring of STZ-diabetic mice revealed biphasic expression of mTORC1 pathway proteins, demonstrating upregulation at 1 month and decreased expression in the following period (Fig. 3a, b). Of note, the upregulation of mTOR activity followed by downregulation has been reported in the other tissues of STZ-induced diabetes models, but the follow-up period lasted only 6 weeks [78]. The biphasic pattern was also observed in GLUT1 expression and activation of mTORC1 pathway correlated with the time point of enhanced expression of GLUT1 (Fig. 3a, b). Thus, activation of the mTOR pathway in the retina of STZ-induced diabetic mice is likely to be in response to hyperglycemia-induced GLUT1 upregulation leading to the increased glucose uptake. These findings have been confirmed by further experiments, where insulin independent glycemic control via PHL treatment resulted in downregulation of mTORC1, pS6 and GLUT1 proteins (Fig. 7a, b). PHL, a natural metabolite isolated from the plants, improves the hyperglycemia by preventing renal glucose resorption and intestinal glucose absorption through suppression of the sodium-glucose transporters [43]. Previous studies demonstrated the protective effect of PHL on the retina from diabetes by decreasing of blood glucose level $[79,80]$, which was also observed in our study (Fig. 2, Table1).

There is no consensus regarding the vascular or neural damage is the earliest morphological consequence of hyperglycemia in the diabetic retina. Nevertheless, the "feed-forward" concept suggests that neuronal dysfunction eventually compromises the overall integrity of the $\mathrm{NVU}$, leading to neurodegeneration and vascular damage [33, 81]. Neurodegeneration is characterized by a decreased thickness of retinal nerve fiber layer, loss of ganglion cells and different types of amacrine cells [19,
$20,24,26]$. Neuronal cell loss was observed as early as after 1 month of STZ-induced diabetes [26]. Apoptosis is proposed to be the main degenerative mechanism in DR [34]. Therefore, we evaluated the immunoreactivity of cleaved caspase 3 in the diabetic retina, which was gradually increased in the GCL over the follow-up period in line with the results of other studies (Fig. 3c, d) [27]. The reduction of NeuN immunoreactivity and the total number of cells in the GCL also indicated hyperglycemiainduced neuronal cell damage (Fig. 3c, e), mirroring the results of previous studies [26]. We assume that there may be a functional relationship between the expression of ribosomal protein $\mathrm{S} 6$ in the GCL and reduced immunoreactivity of NeuN in the diabetic retina (Fig. 4f), since pS6 is one of the downstream effector of mTORC1 pathway on protein synthesis and the part of translational machinery [82]. Further studies are needed to evaluate the significance of neuronal expression of pS6 in the context of neurodegeneration in DR.

One chain of pathological processes triggered by hyperglycemia-related conditions is autophagy, which may cause neurodegeneration in DR [41]. In vitro experiments demonstrated that autophagy strongly depends on the deactivation of the mTORC1 pathway which could be caused by various factors including energy deprivation and hypoxia in terms of the pathogenesis of DR [41, $71,83]$. Inhibition of the mTORC1 pathway initiates the cascades of events leading to the increased expression of autophagic proteins, including LC3B and Beclin1 [71]. Beclin1 is recruited during the early phases of degradative autophagy flux and its upregulation was found to contribute to the initial deregulation of autophagy in human diabetic retinas as well as in STZ-induced diabetes models [36, 38, 84]. To the best of our knowledge, there currently exists no report regarding the involvement of the mTOR pathway in autophagy-induced ganglion cell loss in DR (Additional file 1: Fig. S1). In our study, upregulation of Beclin1 in the entire inner retina was accompanied with the signs of neuronal cell damage, such as activation of apoptotic marker-cleaved caspase 3 and decrease of the total number of cells in the GCL, along with depleted NeuN immunoreactivity in retinal ganglion cells (Figs. 6b and $8 \mathrm{c}-\mathrm{g}$ ). Furthermore, autophagy deregulation was also confirmed by upregulated ATG9A in NeuN positive RGCs of $3 \mathrm{~m}$ DM mouse retina (Additional file 1: Fig. S2). PHL treatment confirmed that hyperglycemia-induced autophagy deregulation is responsible for neuronal cell loss and mTORC1 pathway activity is required to preserve neurons in DR (Fig. 8). The number of apoptotic cells was decreased and NeuN immunoreactivity was higher in the GCL of PHLtreated mice retina comparing to that of $3 \mathrm{~m}$ diabetic control mice (Fig. 8c-g). However, blockade of autophagy 
Long-term hyperglycemia

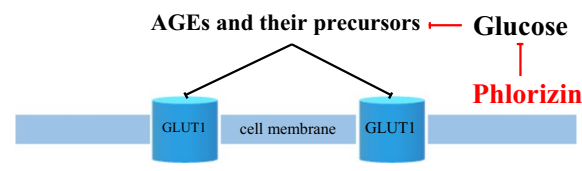

Decreased intracellular glucose level

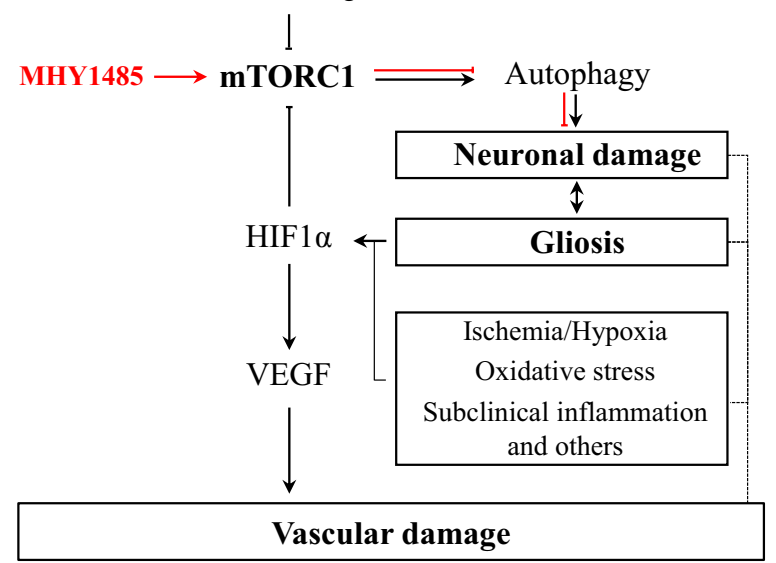

Fig. 9 Schematic representation of the mechanism of neuronal cell rescue by autophagy modulation

by mTOR activator-MHY1485 injections resulted in the more prominent rescue of neuronal cells, as apoptotic cell number in the GCL was the lowest among retinas of all diabetic groups (Fig. 8e). In addition, the total number of cells as well as NeuN positive cells in MHY1485 treated retina was higher than retinas from other diabetic groups (Fig. 8f, g). The less beneficial effect of glycemic control on the ganglion cells comparing to autophagy blockade is likely due to cumulatively inhibition of the mTORC1 pathway by hyperglycemia-related conditions, consequently results in autophagy dysregulation in the diabetic retina. As a result, glycemic control could not fully resolve ganglion cell death in DR (Fig. 8d-f). Moreover, the fact that glycemic control could not restore mTORC1 pathway activity, as we observed in the MHY1485 treated mouse retina, supports this assumption (Fig. 8a). These findings suggest that mTOR pathway plays a crucial role in retinal ganglion cell damage promoted by diabetes and modulation of mTORC1 activity has the rescue effect on the retina through inhibition of autophagy even in uncontrolled hyperglycemia conditions (Fig. 9).

\section{Conclusion}

Our study suggests that during the early period of diabetes, hyperglycemia-induced GLUT1 activation results in increased glucose uptake and mTORC1 signaling activity. However, long-term hyperglycemia-related conditions cause mTOR inhibition leading to autophagy dysregulation, hence the reason for the neuronal cell death in DR. Understanding the mechanism of apoptosis in retinal ganglion cells in the pathogenesis of diabetic retinopathy may reveal novel approaches to prevent the development of the disease at early stages. Also, this study provides the first experimental evidence for the efficacy of mTOR activator-MHY1485 in STZ-induced diabetic retinopathy. Thus, the current study not only describes the mechanisms of neurodegeneration through hyperglycemia-/mTOR/autophagy/apoptosis pathway, but also provides a rationale for the development of new strategies based on autophagy modulation to manage neuronal cell death in the early period of DR.

\section{Supplementary Information}

The online version contains supplementary material available at https:/doi. org/10.1186/s12964-020-00698-4.

Additional file 1: Supplemental Table S1. Details on antibodies. Supplemental Figure $\mathbf{S} 1$. The potential interactions among selected proteins. Network nodes represent proteins (Slc2a1 (GLUT1), Mtor, Rps6, Becn1, Hif1a, Vegfa, GFAP, Casp3, RBFOX3 (NeuN)) of Homo sapiens and Mus musculus. Splice isoforms or posttranslational modifications are collapsed, i.e. each node represents all the proteins produced by a single, proteincoding gene locus. Legends: Node Color: colored nodes: query proteins and first shell of interactors; white nodes: the second shell of interactors Node Content: empty nodes: proteins of unknown 3D structure; filled nodes: some 3D structure is known or predicted Edges represent protein-protein associations. Meaning of network edges: evidence - (a) and molecular action (b). Supplemental Figure S2. Autophagy activation in retinal ganglion cells Immuno-co-staining for ATG9A (green) and NeuN (red) of normal and $3 \mathrm{~m}$ DM mouse retina.

\section{Abbreviations}

AGEs: Advanced glycation end-products; BRB: Blood-retinal barrier; DM: Diabetes mellitus; DR: Diabetic retinopathy; GCL: Ganglion cell layer; GFAP: Glial fibrillary acidic protein; GLUT1: Glucose transporter 1; GS: Glutamine synthetase; INL: Inner nuclear layer; IPL: Inner plexiform layer; mTOR: Mechanistic target of rapamycin; NFL: Nerve fiber layer; NVU: Neurovascular unit; ONL: Outer nuclear layer; PB: Phosphate buffer; PBS: Phosphate-Buffered Saline; PFA: Paraformaldehyde; PHL: Phlorizin.

\section{Acknowledgements}

Not applicable.

\section{Authors' contributions}

Conceptualization, P.T.K. and M.S.B.; Methodology, P.T.K. and M.S.B.; Validation, P.T.K. and M.S.B.; Formal analysis, M.S.B. and Y.J.Y.; Investigation, M.S.B., Y.J.Y., K.J.H. and H.J.W.; Resources, P.T.K.; Writing-Original Draft, M.S.B.; WritingReview \& Editing, P.T.K., M.S.B., and K.J.H.; Visualization, M.S.B., Y.J.Y., K.J.H. and H.J.W.; Supervision, P.T.K. and M.S.B.; Project Administration, P.T.K.; Funding Acquisition, P.T.K. All authors read and approved the final manuscript.

\section{Funding}

This research was supported by Basic Science Research Program through the National Research Foundation of Korea (NRF) funded by the Ministry of Science and ICT (grant number: 2019R1A2C1005055) and partially supported by the Soonchunhyang University research fund.

\section{Availability of data and materials}

The datasets used and/or analyzed during the current study are available from the corresponding author on reasonable request. 


\section{Ethics approval and consent to participate}

All animal experiment was designed and conducted in accordance with the Guide of the Care and Use of Laboratory Animals, the Association for Research in Vision and Ophthalmology Statement for the Use of Animals in Ophthalmic and Vision Research, and approved by the Institutional Animal Care and Use Committee for Soonchunhyang University Hospital Bucheon (SCHBC-animal-2017-04).

\section{Competing interests}

The authors declare no competing interests.

\begin{abstract}
Author details
${ }^{1}$ Department of Interdisciplinary Program in Biomedical Science, Soonchunhyang Graduate School, Bucheon Hospital, Bucheon, South Korea. ${ }^{2}$ Laboratory for Translational Research On Retinal and Macular Degeneration, Soonchunhyang University Hospital Bucheon, Bucheon, South Korea. ${ }^{3}$ Department of Ophthalmology, Soonchunhyang University Hospital Bucheon, Bucheon, South Korea. ${ }^{4}$ Department of Ophthalmology, College of Medicine, Soonchunhyang University, Choongchungnam-do, Cheonan, South Korea. ${ }^{5}$ Department of Ophthalmology, College of Medicine, Soonchunhyang University Bucheon Hospital, Bucheon, South Korea. ${ }^{6}$ Ex Lumina Therapeutics and Technologies. Co., Ltd., Bucheon, South Korea.
\end{abstract}

Received: 11 August 2020 Accepted: 15 December 2020 Published online: 26 February 2021

\section{References}

1. Cheung N, Mitchell P, Wong TY. Diabetic retinopathy. Lancet. 2010;376(9735):124-36. https://doi.org/10.1016/S0140-6736(09)62124-3.

2. Yau JWY, Rogers SL, Kawasaki R, et al. Global prevalence and major risk factors of diabetic retinopathy. Diabetes Care. 2012;35(3):556-64. https:// doi.org/10.2337/dc11-1909.

3. Zhang $X$, Saaddine JB, Chou CF, et al. Prevalence of diabetic retinopathy in the United States, 2005-2008. JAMA J Am Med Assoc. 2010;304(6):64956. https://doi.org/10.1001/jama.2010.1111.

4. Gadkari SS, Maskati QB, Nayak BK. Prevalence of diabetic retinopathy in India: The All India Ophthalmological Society Diabetic Retinopathy Eye Screening Study 2014. Indian J Ophthalmol. 2016;64(1):38-44. https://doi. org/10.4103/0301-4738.178144.

5. Thomas RL, Dunstan FD, Luzio SD, et al. Prevalence of diabetic retinopathy within a national diabetic retinopathy screening service. $\mathrm{Br} J$ Ophthalmol. 2015;99(1):64-8. https://doi.org/10.1136/bjophthalmol-2013-30401 7.

6. Cho NH, Shaw JE, Karuranga S, et al. IDF Diabetes Atlas: Global estimates of diabetes prevalence for 2017 and projections for 2045. Diabetes Res Clin Pract. 2018;138:271-81. https://doi.org/10.1016/j.diabres.2018.02.023.

7. Ting DSW, Cheung GCM, Wong TY. Diabetic retinopathy: global prevalence, major risk factors, screening practices and public health challenges: a review. Clin Exp Ophthalmol. 2016;44(4):260-77. https://doi. org/10.1111/ceo.12696.

8. Flaxman SR, Bourne RRA, Resnikoff S, et al. Global causes of blindness and distance vision impairment 1990-2020: a systematic review and meta-analysis. Lancet Glob Health. 2017;5(12):e1221-34. https://doi. org/10.1016/S2214-109X(17)30393-5.

9. Bandello F, Lattanzio R, Zucchiatti I, Del Turco C. Pathophysiology and treatment of diabetic retinopathy. Acta Diabetol. 2013;50(1):1-20. https:// doi.org/10.1007/s00592-012-0449-3.

10. Wu L, Fernandez-Loaiza P, Sauma J, Hernandez-Bogantes E, Masis M. Classification of diabetic retinopathy and diabetic macular edema. World J Diabetes. 2013;4(6):290. https://doi.org/10.4239/wjd.v4.16.290.

11. Stitt AW, Curtis TM, Chen M, et al. The progress in understanding and treatment of diabetic retinopathy. Prog Retin Eye Res. 2016;51:156-86. https://doi.org/10.1016/j.preteyeres.2015.08.001.

12. Cole ED, Novais EA, Louzada RN, Waheed NK. Contemporary retinal imaging techniques in diabetic retinopathy: a review. Clin Exp Ophthalmol. 2016:44(4):289-99. https://doi.org/10.1111/ceo.12711.

13. Tavares Ferreira J, Alves $M$, Dias-Santos $A$, et al. Retinal neurodegeneration in diabetic patients without diabetic retinopathy. Investig Ophthalmol Vis Sci. 2016;57(14):6455-60. https://doi.org/10.1167/iovs.16-20215.
14. Jackson GR, Barber AJ. Visual dysfunction associated with diabetic retinopathy. Curr Diab Rep. 2010;10(5):380-4. https://doi.org/10.1007/s1189 2-010-0132-4.

15. Han Y, Adams AJ, Bearse MA, Schneck ME. Multifocal electroretinogram and short-wavelength automated perimetry measures in diabetic eyes with little or no retinopathy. Arch Ophthalmol. 2004;122(12):1809-15. https://doi.org/10.1001/archopht.122.12.1809.

16. Harrison WW, Bearse MA, Ng JS, et al. Multifocal electroretinograms predict onset of diabetic retinopathy in adult patients with diabetes. Investig Ophthalmol Vis Sci. 2011;52(2):772-7. https://doi.org/10.1167/ iovs.10-5931.

17. Lecleire-Collet A, Audo I, Aout M, et al. Evaluation of retinal function and flicker light-induced retinal vascular response in normotensive patients with diabetes without retinopathy. Investig Ophthalmol Vis Sci. 2011;52(6):2861-7. https://doi.org/10.1167/iovs.10-5960.

18. Verma A, Raman R, Vaitheeswaran K, et al. Does neuronal damage precede vascular damage in subjects with type 2 diabetes mellitus and having no clinical diabetic retinopathy? Ophthalmic Res. 2012;47(4):202-7. https://doi.org/10.1159/000333220.

19. Vujosevic S, Midena E. Retinal layers changes in human preclinical and early clinical diabetic retinopathy support early retinal neuronal and müller cells alterations. J Diabetes Res. 2013;2013:905058. https://doi. org/10.1155/2013/905058.

20. Barber AJ, Lieth E, Khin SA, Antonetti DA, Buchanan AG, Gardner TW. Neural apoptosis in the retina during experimental and human diabetes: early onset and effect of insulin. J Clin Invest. 1998;102(4):783-91. https:// doi.org/10.1172/JCI2425

21. Carrasco E, Hernandez C, Miralles A, et al. Lower somatostatin expression is an early event in diabetic retinopathy and is. Diabetes Care. 2007;30(11):2902-8. https://doi.org/10.2337/dc07-0332.Additional.

22. Kusari J, Zhou S, Padillo E, Clarke KG, Gil DW. Effect of memantine on neuroretinal function and retinal vascular changes of streptozotocin-induced diabetic rats. Investig Ophthalmol Vis Sci. 2007;48(11):5152-9. https://doi. org/10.1167/iovs.07-0427.

23. Aung $\mathrm{MH}$, Park H, Han MK, et al. Dopamine deficiency contributes to early visual dysfunction in a rodent model of type 1 diabetes. J Neurosci. 2014;34(3):726-36. https://doi.org/10.1523/JNEUROSCI.3483-13.2014.

24. Gastinger MJ, Singh RSJ, Barber AJ. Loss of Cholinergic and dopaminergic amacrine cells in streptozotocin-diabetic rat and Ins $2^{\text {Akita }}$-diabetic mouse retinas. Investig Opthalmology Vis Sci. 2006;47(7):3143. https://doi. org/10.1167/iovs.05-1376.

25. Rungger-Brändle E, Dosso AA, Leuenberger PM. Glial reactivity, an early feature of diabetic retinopathy. Investig Ophthalmol Vis Sci. 2000;41(7):1971-80.

26. Zeng $X X, N g$ YK, Ling EA. Neuronal and microglial response in the retina of streptozotocin-induced diabetic rats. Vis Neurosci. 2000;17(3):463-71. https://doi.org/10.1017/S0952523800173122.

27. Sasaki M, Ozawa Y, Kurihara T, et al. Neurodegenerative influence of oxidative stress in the retina of a murine model of diabetes. Diabetologia. 2010;53(5):971-9. https://doi.org/10.1007/s00125-009-1655-6.

28. Duh EJ, Sun JK, Stitt AW. Diabetic retinopathy: current understanding, mechanisms, and treatment strategies. JCI Insight. 2017. https://doi. org/10.1172/jci.insight.93751.

29. Abcouwer SF, Gardner TW. Diabetic retinopathy: loss of neuroretinal adaptation to the diabetic metabolic environment. Ann NY Acad Sci. 2014;1311:174-90. https://doi.org/10.1111/nyas.12412.

30. Simó R, Hernández C. Novel approaches for treating diabetic retinopathy based on recent pathogenic evidence. Prog Retin Eye Res. 2015;48:16080. https://doi.org/10.1016/j.preteyeres.2015.04.003.

31. Simó R, Stitt AW, Gardner TW. Neurodegeneration in diabetic retinopathy: does it really matter? Diabetologia. 2018;61(9):1902-12. https://doi. org/10.1007/s00125-018-4692-1.

32. Gardner TW, Davila JR. The neurovascular unit and the pathophysiologic basis of diabetic retinopathy. Graefe's Arch Clin Exp Ophthalmol. 2017;255(1):1-6. https://doi.org/10.1007/s00417-016-3548-y.

33. Antonetti DA, Barber AJ, Bronson SK, et al. Diabetic retinopathy: Seeing beyond glucose-induced microvascular disease. Diabetes. 2006;55(9):2401-11. https://doi.org/10.2337/db05-1635.

34. Barber AJ, Gardner TW, Abcouwer SF. The significance of vascular and neural apoptosis to the pathology of diabetic retinopathy. Investig Ophthalmol Vis Sci. 2011;52(2):1156-63. https://doi.org/10.1167/iovs.10-6293. 
35. Simó R, Hernández C. Neurodegeneration is an early event in diabetic retinopathy: Therapeutic implications. Br J Ophthalmol. 2012;96(10):1285-90. https://doi.org/10.1136/bjophthalmol-2012-30200 5.

36. Piano I, Novelli E, Della Santina L, Strettoi E, Cervetto L, Gargini C. Involvement of autophagic pathway in the progression of retinal degeneration in a mouse model of diabetes. Front Cell Neurosci. 2016;10(FEB):42. https ://doi.org/10.3389/fncel.2016.00042.

37. Park H-YL, Kim JH, Park CK. Different contributions of autophagy to retinal ganglion cell death in the diabetic and glaucomatous retinas. Sci Rep. 2018;8(1):13321. https://doi.org/10.1038/s41598-018-30165-7.

38. De Faria JMLJBL, Duarte DA, Montemurro C, et al. Defective autophagy in diabetic retinopathy. Investig Ophthalmol Vis Sci. 2016;57(10):4356-66. https://doi.org/10.1167/iovs.16-19197.

39. Lin WJ, Kuang HY. Oxidative stress induces autophagy in response to multiple noxious stimuli in retinal ganglion cells. Autophagy. 2014;10(10):1692-701. https://doi.org/10.4161/auto.36076.

40. Jung HS, Lee MS. Role of autophagy in diabetes and mitochondria. In: Annals of the New York Academy of Sciences, vol 1201. New York: Blackwell Publishing Inc.; 2010:79-83. https://doi.org/10.111 1/j.1749-6632.2010.05614.x

41. Di RM, Distefano G, Gagliano C, Rusciano D, Malaguarnera L. Autophagy in diabetic retinopathy. Curr Neuropharmacol. 2016;14(8):810-25. https://doi.org/10.2174/1570159X146661603211 22900.

42. Saha S, Panigrahi DP, Patil S, Bhutia SK. Autophagy in health and disease: a comprehensive review. Biomed Pharmacother. 2018;104:48595. https://doi.org/10.1016/j.biopha.2018.05.007.

43. Ehrenkranz JRL, Lewis NG, Kahn CR, Roth J. Phlorizin: a review. Diabetes Metab Res Rev. 2005;21(1):31-8. https://doi.org/10.1002/dmrr.532.

44. Fort PE, Losiewicz MK, Reiter CEN, et al. Differential roles of hyperglycemia and hypoinsulinemia in diabetes induced retinal cell death: evidence for retinal insulin resistance. PLoS ONE. 2011. https://doi. org/10.1371/journal.pone.0026498.

45. Sällström J, Eriksson T, Fredholm BB, Persson AEG, Palm F. Inhibition of sodium-linked glucose reabsorption normalizes diabetes-induced glomerular hyperfiltration in conscious adenosine A1-receptor deficient mice. Acta Physiol. 2014;210(2):440-5. https://doi.org/10.1111/ apha.12152.

46. Yang JY, Madrakhimov SB, Ahn DH, et al. mTORC1 and mTORC2 are differentially engaged in the development of laser-induced CNV. Cell Commun Signal. 2019;17(1):64. https://doi.org/10.1186/s1296 4-019-0380-0.

47. Li J, Kim SG, Blenis J. Rapamycin: one drug, many effects. Cell Metab. 2014;19(3):373-9. https://doi.org/10.1016/j.cmet.2014.01.001.

48. Choi YJ, Park YJ, Park JY, et al. Inhibitory effect of mTOR activator MHY1485 on autophagy: suppression of lysosomal fusion. PLoS ONE. 2012. https://doi.org/10.1371/journal.pone.0043418.

49. Zhou J, Yao W, Li C, Wu W, Li Q, Liu H. Administration of folliclestimulating hormone induces autophagy via upregulation of HIF-1a in mouse granulosa cells. Cell Death Dis. 2017;8(8):e3001. https://doi. org/10.1038/cddis.2017.371.

50. Jampol LM, Glassman AR, Sun J. Evaluation and care of patients with diabetic retinopathy. N Engl J Med. 2020;382(17):1629-37. https://doi. org/10.1056/NEJMra1909637.

51. Kumagai AK. Glucose transport in brain and retina: Implications in the management and complications of diabetes. Diabetes Metab Res Rev. 1999;15(4):261-73. https://doi.org/10.1002/(SICI)1520-7560(19990 7/08)15:4\%3c261::AID-DMRR43\%3e3.0.CO;2-Z.

52. Kumagai AK, Glasgow BJ, Pardridge WM. GLUT1 glucose transporter expression in the diabetic and nondiabetic human eye. Investig Ophthalmol Vis Sci. 1994;35(6):2887-94.

53. Takata K, Kasahara T, Kasahara M, Ezaki O, Hirano H. Ultracytochemical localization of the erythrocyte/HepG2-type glucose transporter (GLUT1) in cells of the blood-retinal barrier in the rat. Investig Ophthalmol Vis Sci. 1992:33(2):377-83.

54. Gospe SM, Baker SA, Arshavsky VY. Facilitative glucose transporter Glut1 is actively excluded from rod outer segments. J Cell Sci. 2010;123(Pt 21):3639-44. https://doi.org/10.1242/jcs.072389.

55. Mantych GJ, Hageman GS, Devaskar SU. Characterization of glucose transporter isoforms in the adult and developing human eye. Endocrinology. 1993;133(2):600-7. https://doi.org/10.1210/ endo.133.2.8344201.

56. Thorens B, Mueckler M. Glucose transporters in the 21 st Century. Am J Physiol Endocrinol Metab. 2010. https://doi.org/10.1152/ajpen do.00712.2009.

57. Calado SM, Alves LS, Simão S, Silva GA. GLUT1 activity contributes to the impairment of PEDF secretion by the RPE. Mol Vis. 2016;22:761-70.

58. Cloherty EK, Diamond DL, Heard KS, Carruthers A. Regulation of GLUT1mediated sugar transport by an antiport/uniport switch mechanism. Biochemistry. 1996;35(40):13231-9. https://doi.org/10.1021/bi961208t.

59. Adachi-Uehara N, Kato M, Nimura Y, et al. Up-regulation of genes for oxidative phosphorylation and protein turnover in diabetic mouse retina. Exp Eye Res. 2006;83(4):849-57. https://doi.org/10.1016/j. exer.2006.04.012.

60. Nyengaard JR, Ido Y, Kilo C, Williamson JR. Interactions between diabetes and hypoxia retinopathy 2004 implications for diabetic retinopathy. Diabetes. 2004;53:2931-8.

61. Imai H, Singh RSJ, Fort PE, Gardner TW. Neuroprotection for diabetic retinopathy. Dev Ophthalmol. 2009;44:56-68. https://doi. org/10.1159/000223946.

62. Fernandes R, Suzuki K, Kumagai AK. Inner blood-retinal barrier GLUT1 in long-term diabetic rats: an immunogold electron microscopic study. Investig Ophthalmol Vis Sci. 2003;44(7):3150-4. https://doi. org/10.1167/iovs.02-1284.

63. Fernandes R, Carvalho AL, Kumagai A, et al. Downregulation of retinal GLUT1 in diabetes by ubiquitinylation. Mol Vis. 2004;10:618-28.

64. Badr GA, Tang J, Ismail-Beigi F, Kern TS. Diabetes downregulates GLUT1 expression in the retina and its microvessels but not in the cerebral cortex or its microvessels. Diabetes. 2000;49(6):1016-21. https://doi. org/10.2337/diabetes.49.6.1016.

65. Kumagai AK, Vinores SA, Pardridge WM. Pathological upregulation of inner blood-retinal barrier Glut1 glucose transporter expression in diabetes mellitus. Brain Res. 1996;706(2):313-7. https://doi. org/10.1016/0006-8993(95)01335-0.

66. Tang J, Mohr S, Du YP, Kern TS. Non-uniform distribution of lesions and biochemical abnormalities within the retina of diabetic humans. Curr Eye Res. 2003;27(1):7-13. https://doi.org/10.1076/ceyr.27.2.7.15455.

67. Roy A, Hashmi S, Li Z, Dement AD, Cho KH, Kim JH. The glucose metabolite methylglyoxal inhibits expression of the glucose transporter genes by inactivating the cell surface glucose sensors Rgt2 and Snf3 in yeast. Mol Biol Cell. 2016;27(5):862-71. https://doi.org/10.1091/ mbc.E15-11-0789.

68. Stenina O. Regulation of vascular genes by glucose. Curr Pharm Des. 2005;11(18):2367-81. https://doi.org/10.2174/1381612054367283.

69. Stitt AW. AGEs and diabetic retinopathy. Investig Ophthalmol Vis Sci. 2010;51(10):4867-74. https://doi.org/10.1167/iovs.10-5881.

70. Kim D-I, Lim S-K, Park M-J, Han H-J, Kim G-Y, Park SH. The involvement of phosphatidylinositol 3-kinase /Akt signaling in high glucoseinduced downregulation of GLUT-1 expression in ARPE cells. Life Sci. 2007;80(7):626-32. https://doi.org/10.1016/J.LFS.2006.10.026.

71. Dehdashtian E, Mehrzadi S, Yousefi B, et al. Diabetic retinopathy pathogenesis and the ameliorating effects of melatonin; involvement of autophagy, inflammation and oxidative stress. Life Sci. 2018;193:20-33. https://doi.org/10.1016/j.lfs.2017.12.001.

72. Saxton RA, Sabatini DM. mTOR Signaling in Growth, Metabolism, and Disease. Cell. 2017;168(6):960-76. https://doi.org/10.1016/j. cell.2017.02.004

73. Harwood FC, Klein Geltink RI, O'Hara BP, et al. ETV7 is an essential component of a rapamycin-insensitive mTOR complex in cancer. Sci Adv. 2018. https://doi.org/10.1126/sciadv.aar3938.

74. Wellen KE, Thompson CB. Cellular metabolic stress: considering how cells respond to nutrient excess. Mol Cell. 2010:40(2):323-32. https:// doi.org/10.1016/j.molcel.2010.10.004

75. Buller CL, Heilig CW, Brosius FC. GLUT1 enhances mTOR activity independently of TSC2 and AMPK. Am J Physiol Ren Physiol. 2011;301(3):F588-96. https://doi.org/10.1152/ajprenal.00472.2010.

76. Lu L, Seidel CP, Iwase T, et al. Suppression of GLUT1; A new strategy to prevent diabetic complications. J Cell Physiol. 2013;228(2):251-7. https ://doi.org/10.1002/jcp.24133.

77. Wei J, Jiang H, Gao H, Wang G. Blocking Mammalian target of rapamycin (mTOR) attenuates HIF-1 a pathways engaged-vascular endothelial 
growth factor (VEGF) in diabetic retinopathy. Cell Physiol Biochem. 2016:40(6):1570-7. https://doi.org/10.1159/000453207.

78. Zhang MH, Jiang JZ, Cai YL, Piao LH, Jin Z. Significance of dynamic changes in gastric smooth muscle cell apoptosis, PI3K-AKT-mTOR and AMPK-mTOR signaling in a rat model of diabetic gastroparesis. Mol Med Rep. 2017;16(2):1530-6. https://doi.org/10.3892/mmr.2017.6764.

79. Shen L, You B, Gao H, Li B, Yu F, Pei F. Effects of phlorizin on vascular complications in diabetes $\mathrm{db} / \mathrm{db}$ mice. Chin Med J Engl. 2012;125(20):3692-6. https://doi.org/10.3760/cma.j.i ssn.0366-6999.2012.20.017.

80. Zhang S, Li B, Li X, et al. Effects of phlorizin on diabetic retinopathy according to isobaric tags for relative and absolute quantificationbased proteomics in db/db mice. Mol Vis. 2013;19:812-21.

81. Lechner J, O'Leary OE, Stitt AW. The pathology associated with diabetic retinopathy. Vis Res. 2017;139:7-14. https://doi.org/10.1016/j.visre s.2017.04.003.
82. Morita M, Gravel SP, Hulea L, et al. MTOR coordinates protein synthesis, mitochondrial activity. Cell Cycle. 2015;14(4):473-80. https://doi. org/10.4161/15384101.2014.991572.

83. Alers S, Loffler AS, Wesselborg S, Stork B. Role of AMPK-mTOR-Ulk1/2 in the regulation of autophagy: cross talk, shortcuts, and feedbacks. Mol Cell Biol. 2012;32(1):2-11. https://doi.org/10.1128/mcb.06159-11.

84. Fu D, Yu JY, Yang S, et al. Survival or death: a dual role for autophagy in stress-induced pericyte loss in diabetic retinopathy. Diabetologia. 2016;59(10):2251-61. https://doi.org/10.1007/s00125-016-4058-5.

\section{Publisher's Note}

Springer Nature remains neutral with regard to jurisdictional claims in published maps and institutional affiliations.
Ready to submit your research? Choose BMC and benefit from:

- fast, convenient online submission

- thorough peer review by experienced researchers in your field

- rapid publication on acceptance

- support for research data, including large and complex data types

- gold Open Access which fosters wider collaboration and increased citations

- maximum visibility for your research: over $100 \mathrm{M}$ website views per year

At BMC, research is always in progress.

Learn more biomedcentral.com/submissions 